\title{
Synthesis of novel $\alpha$-functionalized phosphinic acid derivatives of thiophene and the first crystal structure of an $\alpha$-hydroxyalkylphosphinate
}

\author{
S. W. Annie Bligh, ${ }^{*} \dagger \dagger_{\dagger}$ Carlos F. G. C. Geraldes, ${ }^{b}$ Mary McPartlin, ${ }^{a}$ Mahesh J. Sanganee $^{a}$ and Thomas M. \\ Woodroffe $a$ \\ a School of Biological and Applied Sciences, University of North London, Holloway Road, London, UK N7 8DB \\ ${ }^{b}$ Department of Biochemistry and Centre of Neurosciences, University of Coimbra, 3000 Coimbra, Portugal
}

\begin{abstract}
Reaction of 2,5-diformylthiophene with $\mathrm{Ph}_{2} \mathrm{CHNH}_{2}$ and hypophosphorus acid yields novel $\alpha$-hydroxy- or $\alpha$-aminomethylphosphinic acid derivatives depending on reaction conditions; the X-ray structure analysis of diphenylmethylammonium 5-formyl-2-thienyl(hydroxy)methylphosphinate provides the first direct structural information on the $\alpha$-hydroxyalkylphosphinate class of compounds.
\end{abstract}

Compounds containing an $\alpha$-aminoalkylphosphinic acid functional group are of considerable importance because of their anti-bacterial, ${ }^{1}$ herbicidal ${ }^{2}$ and fungicidal ${ }^{3}$ activities. Protonation studies of $\alpha$-aminomethylphosphinic acids $\left[\mathrm{R}_{2} \mathrm{NCH}_{2} \mathrm{P}(\mathrm{H}) \mathrm{O}_{2} \mathrm{H}\right]$ have shown that the nitrogen atom is very weakly basic compared to those of $\alpha$-aminomethylphosphonic acids $\left(\mathrm{R}_{2} \mathrm{NCH}_{2} \mathrm{PO}_{3} \mathrm{H}_{2}\right)$ and $\alpha$-aminocarboxylic acids $\left(\mathrm{R}_{2} \mathrm{NCH}_{2} \mathrm{CO}_{2} \mathrm{H}\right)$, and that the phosphinic acid group is strongly acidic. ${ }^{4}$ In contrast to the widely studied $\alpha$-aminoalkylphosphinic acid derivatives, relatively few papers have been reported on the chemistry of $\alpha$-hydroxyalkylphosphinic acids, although there is evidence that $\alpha$-hydroxyalkylphosphinate esters are pharmaceutically active. 5 Many effective methods for the preparation of $\alpha$-aminoalkylphosphinic acids have been developed, ${ }^{6}$ but few synthetic routes to $\alpha$-hydroxyalkylphosphinic acids have been reported and these involve prolonged heating of hypophosphorous acids with aldehydes or ketones, ${ }^{7}$ or reaction of ketones with bis(trimethylsilyloxy)phosphine. ${ }^{8}$ Here we have successfully prepared both types of $\alpha$-functionalised phosphinates (Scheme 1); of particular importance is the isolation for the first time of the $\alpha$-hydroxyalkylphosphinate compound using rela-

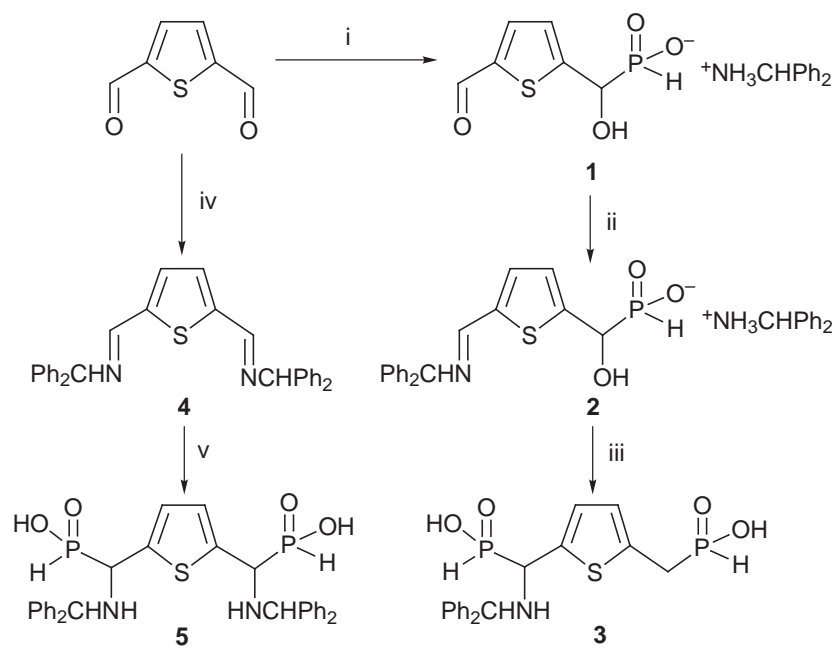

Scheme 1 Reagents and conditions: i, $\mathrm{Ph}_{2} \mathrm{CHNH}_{2}, 50 \%$ aq $\mathrm{H}_{3} \mathrm{PO}_{2}, 30 \%$; ii, $\mathrm{Ph}_{2} \mathrm{CHNH}_{2}$, DMSO, 88\%; iii, $\mathrm{H}_{3} \mathrm{PO}_{2}, 1$,4-dioxane, 26\%; iv, $\mathrm{Ph}_{2} \mathrm{CHNH}_{2}$, $\mathrm{MeOH}, 51 \%$; v, $\mathrm{H}_{3} \mathrm{PO}_{2}, 1,4$-dioxane, $72 \%$ tively mild reaction conditions, and the first characterisation by $\mathrm{X}$-ray crystallography of this class of compound.

The reaction of 2,5-diformylthiophene (prepared as described in ref. 9) with $\mathrm{Ph}_{2} \mathrm{CHNH}_{2}$ and aqueous hypophosphorous acid $(50 \%)$ gives an unexpected mono( $\alpha$-hydroxyalkylphosphinate) derivative 1 rather than the bis( $\alpha$-aminoalkylphosphinate) derivative 5. The remaining thiophene carbonyl group is not electrophilic towards the addition of a second water molecule to form the intermediate gem-diol; all attempts to prepare the bis $(\alpha$-hydroxyalkylphosphinate) derivative proved unsuccessful.

The presence of the $\alpha$-hydroxy group in 1 was confirmed by X-ray structure analysis $\ddagger$ of the (diphenylmethyl)ammonium salt and the structure of the ions, linked by a hydrogen bond between one of the phosphinate oxygen atoms and a proton of the ammonium cation $[\mathrm{O}(2) \cdots \mathrm{H}(1 \mathrm{~N})=1.86 \AA]$ is shown in Fig. 1(a). The remaining two protons of the (diphenylmethyl)ammonium counterion are also involved in hydrogen-bonding to phosphinate oxygen atoms of adjacent symmetry related anions $[\mathrm{O} \cdots \mathrm{H}(\mathrm{N})=1.72-1.90 \AA]$, resulting in a complicated spiral hydrogen bonded chain of alternating cations and anions running parallel to the $b$ axis of the crystal [Fig. 1(b)]. Along this helix, adjacent anions (separated by the $b$ axis length) are linked by hydrogen-bonding between the $\alpha$-hydroxy group of one and a phosphinate oxygen of the next $\left[\mathrm{H}(1 \mathrm{O}) \cdots \mathrm{O}\left(3^{\prime}\right)=1.98\right.$ $\AA]$ as can also be seen in Fig. $1(b)$.

In order to prepare the bis $(\alpha$-aminoalkylphosphinate) derivative 5 from the dialdehyde a two stage process was required. The carbonyl groups were first converted to the imine functions by condensing the dialdehyde and $\mathrm{Ph}_{2} \mathrm{CHNH}_{2}$ in $\mathrm{MeOH}$ to give $\mathbf{4}$, and addition of hypophosphorous acid (100\%) to $\mathbf{4}$ in 1,4-dioxane gives a diastereoisomeric mixture of $\mathbf{5}$ in good yield. However, the addition of hypophosphorous acid (100\%) to the mono-imine derivative 2 readily converts the imine to the $\alpha$-aminoalkylphosphinate, and the presence of excess hypophosphorous acid reduces the $\alpha$-hydroxy functional group to yield 3. Attempts to remove the $\mathrm{Ph}_{2} \mathrm{CH}$ protecting groups have proved difficult. The new compounds 1-5 give satisfactory elemental analysis and their ${ }^{1} \mathrm{H},{ }^{13} \mathrm{C}$ and ${ }^{31} \mathrm{P}$ NMR data§ agree with the structures proposed. Both compounds $\mathbf{1}$ and $\mathbf{2}$ have been tested in the antibacterial screen and showed no activity.

Compound $\mathbf{1}$ is the first example of an $\alpha$-hydroxyalkylphosphinate as a substituent of a heterocyclic ring. The ability to derivatize only one of the two aldehyde groups to afford the mono( $\alpha$-hydroxyalkylphosphinate) opens up the possibility that the remaining carbonyl can be used in further reaction with an amine [e.g. Scheme 1(ii)]. This availability of an additional active carbonyl in an $\alpha$-hydroxyalkylphosphinate derivative is thus potentially beneficial for its coupling to biological macromolecules or to polymers for selective metal complexation applications.

We thank GlaxoWellcome (to M. J. S.) for financial support, the EPSRC for a studentship (to T. M. W.) and for use of the Chemical Database Service at Daresbury. S. W. A. B. thanks The Royal Society (European Science Exchange Programme) 


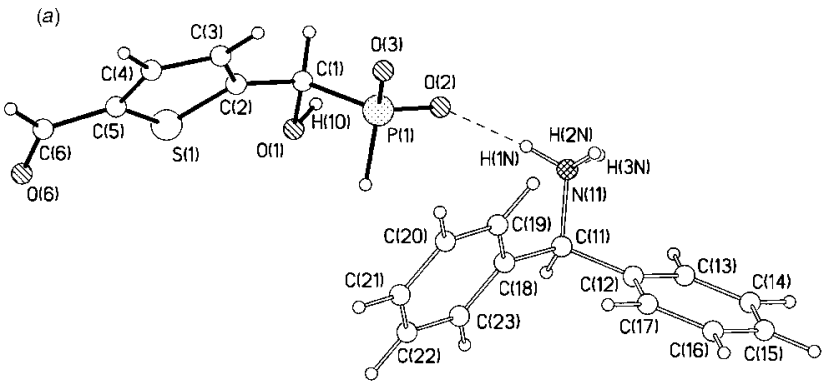

(b)

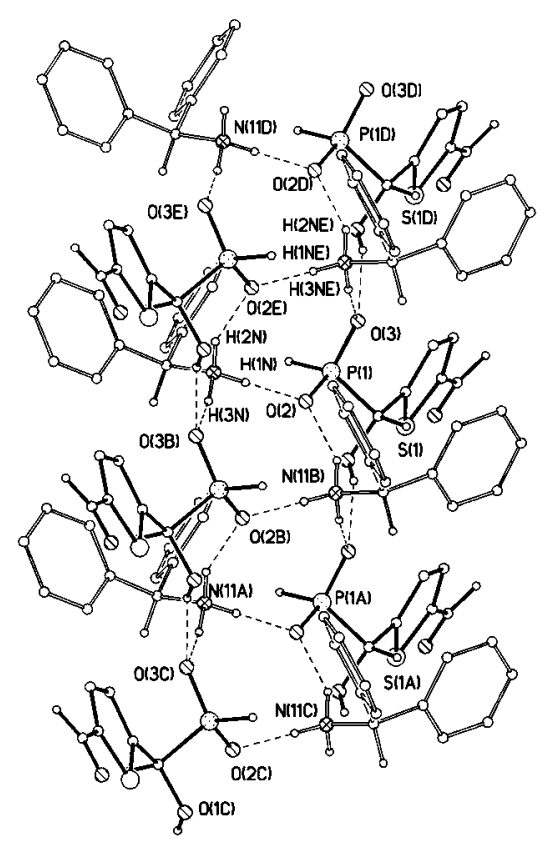

Fig. 1 The structure of 1: (a) the anion and cation linked by one of the H-bonds (only the major component of the rotationally disorder formyl group is shown); (b) part of the helical $\mathrm{H}$-bonded chain generated by the $2_{1}$ screw axis parallel to $b$ (the symmetry related ions are at $\mathrm{A}: x,-1+y, z$; $\mathrm{B}$ : $0.5-x,-0.5+y, 0.5-z ; \mathrm{C}: 0.5-x,-1.5+y, 0.5-z ; \mathrm{D}: x, 1+y, z ; \mathrm{E}$ : $0.5-x, 0.5+y, 0.5-z)$

for financial support. C.F.G.C.G. thanks Junta Nacional de Investigaç:o Cientifica e Technológic, Portugal for financial support.

\section{Notes and References}

$\dagger$ E-mail: a.bligh@unl.ac.uk

$\$$ Crystal data for 1 : $\mathrm{C}_{19} \mathrm{H}_{20} \mathrm{NO}_{4} \mathrm{PS}, M=389.2$, pale brown crystal $(0.50 \times$ $0.38 \times 0.34 \mathrm{~mm}^{3}$ ), monoclinic, space group $P 2_{1} / \mathrm{n}$ (No. 14), $a=15.773(3)$, $b=5.894(2), c=21.404(4) \AA, \beta=104.06(4)^{\circ}, U=1930.2 \AA^{3}, Z=4$, $F(000)=776, D_{c}=1.278 \mathrm{~g} \mathrm{~cm}^{-3}, \mu(\mathrm{Mo}-\mathrm{K} \alpha)=0.26 \mathrm{~mm}^{-1}, \lambda=0.71069$ $\AA$ (graphite monochromator). Data were collected on a Philips PW1100 diffractometer in the $\theta$ range $3-23^{\circ}$ with a scan width of $0.90^{\circ}$. The structure was solved by direct methods (ref. 10); the H-atoms of the ammonium and hydroxy group were located from difference-Fourier syntheses, but were not refined, and the remaining $\mathrm{H}$-atoms were included at idealised positions. Anisotropic displacement parameters were assigned to all non-hydrogen atoms (apart from the phenyl $\mathrm{C}$-atoms, which were constrained to idealised hexagons, $\mathrm{C}-\mathrm{C} 1.395 \AA$ ) in the final cycles of full-matrix refinement based on $F$ (ref. 11) which converged at $R=0.0561\left(R_{w}=0.0581, w=1 / \sigma^{2} F_{\mathrm{o}}\right)$ for 1259 unique reflections having $I / \sigma(I) \geqslant 3.0$ and 174 variables. CCDC 182/972.

$\S$ Selected data for 1: $\delta_{\mathrm{H}}\left(250 \mathrm{MHz},\left[{ }^{2} \mathrm{H}_{6}\right] \mathrm{DMSO}\right) 9.81(\mathrm{~s}, 1 \mathrm{H}, \mathrm{CHO}), 9.37$ $(\mathrm{s}, \mathrm{NH}), 7.64(\mathrm{~m}, 1 \mathrm{H}$, thiophene $), 7.35(\mathrm{~m}, 10 \mathrm{H}, \mathrm{Ph}), 7.10,(\mathrm{~m}, 1 \mathrm{H}$, thiophene), $6.77\left(\mathrm{~d}, 1 \mathrm{H}, J_{\mathrm{PH}} 552, \mathrm{PH}\right), 5.51\left(\mathrm{~s}, 1 \mathrm{H}, \mathrm{CHPh}_{2}\right), 4.70(\mathrm{~d}, 1 \mathrm{H}$, $\left.{ }^{2} J_{\mathrm{P}-\mathrm{CH}} 10.0, \mathrm{CH}\right) ; \delta_{\mathrm{P}} 19.35 ; \delta_{\mathrm{C}} 183.6(\mathrm{HCO}), 147.2,137.2,132.4,124.5$, 134.6 (thiophene), 138.2, 128.6, 128.1, $127.1(\mathrm{Ph}), 69.1\left(\mathrm{~d}, J_{\mathrm{PC}} 107, \mathrm{CP}\right)$ $56.9\left(\mathrm{CHPh}_{2}\right)$. For 2: $\delta_{\mathrm{H}}\left(250 \mathrm{MHz},\left[{ }^{2} \mathrm{H}_{6}\right] \mathrm{DMSO}\right) 8.87(\mathrm{~s}, \mathrm{NH}), 8.55(\mathrm{~s}, 1 \mathrm{H}$, $\mathrm{HCN}), 7.25(\mathrm{~m}, 21 \mathrm{H}, \mathrm{Ph}$ and thiophene $), 6.90(\mathrm{~m}, 1 \mathrm{H}$, thiophene $), 6.64(\mathrm{~d}$, $\left.1 \mathrm{H}, J_{\mathrm{PH}} 489, \mathrm{PH}\right), 5.62,5.47\left(\mathrm{~s}, 2 \mathrm{H}, \mathrm{CHPh}_{2}\right), 4.49\left(\mathrm{~d}, 1 \mathrm{H},{ }^{2} J_{\mathrm{P}-\mathrm{CH}} 11.8, \mathrm{CH}\right)$ $\delta_{\mathrm{P}} 20.49 ; \delta_{\mathrm{C}} 1854.8(\mathrm{HCN}), 150.0,139.5,131.4,123.4$ (thiophene), 144.2, 139.2, 128.5, 128.1, 127.8, 127.1, 126.6 (Ph), $71.2\left(\mathrm{~d}, J_{\mathrm{PC}} 149, \mathrm{CP}\right), 75.7$, $56.9\left(\mathrm{CHPh}_{2}\right)$. For 3: $\delta_{\mathrm{H}}\left(250 \mathrm{MHz},\left[{ }^{2} \mathrm{H}_{6}\right] \mathrm{DMSO}\right) 7.46-7.19(\mathrm{~m}, 11 \mathrm{H}, \mathrm{Ph}$ and thiophene), $6.84\left(\mathrm{~s}, 1 \mathrm{H}\right.$, thiophene), $6.91\left(\mathrm{~d}, 2 \mathrm{H}, J_{\mathrm{PH}} 530, \mathrm{PH}\right), 6.82(\mathrm{~d}$, $\left.2 \mathrm{H}, J_{\mathrm{PH}} 510, \mathrm{PH}\right), 5.05\left(\mathrm{~s}, 1 \mathrm{H}, \mathrm{CHPh}_{2}\right), 3.78\left(\mathrm{~d}, 1 \mathrm{H},{ }^{2} J_{\mathrm{P}-\mathrm{CH}} 16.5, \mathrm{CH}\right), 3.26$ $\left(\mathrm{d}, 1 \mathrm{H},{ }^{2} J_{\mathrm{P}-\mathrm{CH}} 17.5, \mathrm{CH}_{2}\right) ; \delta_{\mathrm{P}} 27.76,27.00 ; \delta_{\mathrm{C}} 146.6,145.5,141.5$, 137.0,132.5, 131.3, 131.1, 130.7 (thiophene and $\mathrm{Ph}), 67.4\left(\mathrm{CHPh}_{2}\right), 60.1(\mathrm{~d}$, $\left.J_{\mathrm{PC}} 101, \mathrm{HCP}\right), 36.2\left(\mathrm{~d}, J_{\mathrm{PC}} 88.2, \mathrm{H}_{2} \mathrm{CP}\right)$. For $4: \delta_{\mathrm{H}}\left(250 \mathrm{MHz},\left[{ }^{2} \mathrm{H}_{6}\right] \mathrm{DMSO}\right)$ $8.66(\mathrm{~s}, 2 \mathrm{H}, \mathrm{HCN}), 7.52(\mathrm{~s}, 2 \mathrm{H}$, thiophene), 7.41-7.19 (m, 20H, Ph), $5.70(\mathrm{~s}$, $\left.2 \mathrm{H}, \mathrm{CHPh}_{2}\right) ; \delta_{\mathrm{C}} 154.9(\mathrm{HCN}), 144.5,132.1$ (thiophene), 143.9, 128.4, 127.1, $126.8(\mathrm{Ph}), 75.8\left(\mathrm{CHPh}_{2}\right)$. For 5: diastereoisomers $(*) \delta_{\mathrm{H}}(250 \mathrm{MHz}$, $\left.\left[{ }^{2} \mathrm{H}_{6}\right] \mathrm{DMSO}\right) 7.35(\mathrm{~m}, 21 \mathrm{H}, \mathrm{Ph}$ and thiophene $), 6.95,6.88^{*}(\mathrm{~s}, 1 \mathrm{H}$, thiophene), $6.92\left(\mathrm{~d}, 1 \mathrm{H}, J_{\mathrm{PH}} 546, \mathrm{PH}\right), 5.07,5.04 *\left(\mathrm{~s}, 1 \mathrm{H}, \mathrm{CHPh}_{2}\right), 3.89$, $3.83^{*}\left(\mathrm{~d}, 1 \mathrm{H},{ }^{2} J_{\mathrm{P}-\mathrm{CH}} 17.0, \mathrm{CH}\right) ; \delta_{\mathrm{P}} ; 27.26,27.01^{*} ; \delta_{\mathrm{C}} 146.6,146.3^{*}, 145.3$, $145.1^{*}, 142.6,142.0,132.7,132.5,132.2,131.4,131.0$ ( $\mathrm{Ph}$ and thiophene), $67.5,67.4 *\left(\mathrm{CHPh}_{2}\right), 60.3,60.1 *\left(\mathrm{~d}, J_{\mathrm{PC}} 101, \mathrm{CP}\right)$.

1 J. G. Dingwall, C. D. Campell and E. K. Baylis, UK Pat. Appl., 1542 938, 1979.

2 P. Kafarski, B. Lejczak, R. Tyka, L. Koba, E. Pliszczak and P. Wieczorek, J. Plant Growth Regulation, 1995, 14, 199.

3 Y. Ishiguri, Y. Yamada, T. Kato, M. Sasaki and K. Mukai, Eur. Pat. Appl., EP 82-301905, 1982.

4 T. Kiss, M. Jezowska-Bojczuk, H. Kozlowski, P. Kafarski and K. Antczak, J. Chem. Soc., Dalton Trans., 1991, 2275; R. J. Motekaitis, I. Murase and A. E. Martell, J. Inorg. Nucl. Chem., 1971, 33, 3353.

5 E. K. Baylis, Eur. Pat. Appl., EP-614900, 1994.

6 E. K. Baylis, C. D. Campbell and J. G. Dingwall, J. Chem. Soc., Perkin Trans., 1, 1984, 2845; D. Grobelny, Synthesis, 1987, 94; X. Jiao, C. Verbraggen, M. Borloo, W. Bollaert, A. De Groot, R. Dommisse and A. Haemers, Synthesis, 1994, 23.

7 M. C. Marie, Compt. Rend., 1904, 138, 1707.

8 V. I. Vysotskii and S. V. Levan'kov, Zh. Obshch. Khim., 1991, 61, 1315.

9 T. Mitsumori, K. Inoue, N. Koya and H. Iwamura, J. Am. Chem. Soc., 1995, 117, 2467.

10 G. M. Sheldrick, SHELX 86, Program for Crystal Structure Solution, Göttingen, 1986.

11 G. M. Sheldrick, SHELX 76, Program for Crystal Structure Determination, Cambridge, 1976.

Received in Cambridge, UK, 6th July 1998; 8/05189E 